\title{
Application of recycled natural aluminasilicate doped with vanadium for the decontamination of the air
}

\author{
${ }^{1}$ Agnieszka Marcewicz-Kuba, ${ }^{2}$ Danuta Olszewska \\ ${ }^{1}$ Maria Curie-Sklodowska University, Faculty of Chemistry, Pl. M. Curie-Skłodowskiej 3, 20-031 Lublin, Poland, \\ e-mail: amarcewi@hermes.umcs.lublin.pl \\ ${ }^{2}$ AGH University of Science and Technology, Faculty of Fuel and Energy, al. A. Mickiewicza 30, 30-059 Cracow, Poland
}

This paper reports studies on the influence of vanadium concentration on the catalytic activity of DESONOX catalysts (in DESOX reaction) based on modified montmorillonite from Jelsovy Potok. The investigation of the influence on the physicochemical properties of the catalysts on their behaviour has also been studied.

Keywords: DESONOX catalysts, $\mathrm{SO}_{2}$ removal, montmorillonite, vanadium.

Presented at VII Conference Wasteless Technologies and Waste Management in Chemical Industry and Agriculture, Międzyzdroje, 12 - 15 June, 2007.

\section{INTRODUCTION}

Combustion of hard coal causes emission of gaseous chemicals $\left(\mathrm{SO}_{2}, \mathrm{NO}_{\mathrm{x}}\right)$, airborne particles and fly ashes into the atmosphere ${ }^{1}$. Sulphur dioxide is one of the chemicals emitted during the process of hard coal combustion. The desulphurization of solid fuels is one of the main ways of decreasing the environmental impact of their combustion product. The catalytic process of $\mathrm{SO}_{2}$ removal from combustion gases takes place on the grain plane of hard coal. The method proposed for the removal of $\mathrm{SO}_{2}$ from combustion gases is quite different from the classical wet desulphurization methods ${ }^{2}$. This solution eliminates the technically complicated wet desulphurization of exhausts: sulphur within the hard coal reacts with catalyst compounds, what enriches the ashes with sulphates ${ }^{3-4}$. The technical research ${ }^{5}$ has shown that DESONOX type catalyst causes the lowering of both sulphur dioxide and nitrogen oxide emissions from the exhaust coming from the combustion of the solid fuels.

The main aim of the paper is to study the influence of vanadium on the catalytic activity of DESONOX catalyst (in DESOX reaction) based on modified montmorillonite. The research results of the influence of catalysts' physicochemical properties on their activity are also studied. The authors compared the catalyst effectively removing $\mathrm{SO}_{2}$ from the combustion gases by catalyst with vanadium introduced by support at different time periods.

\section{EXPERIMENTAL}

\section{Catalysts}

The starting natural material was the montmorillonite from Jelsovy Potok from Slovakia. The composition of this material (wt. \%) as given by the X-ray fluorescence method XRF is: $\mathrm{N}_{2} \mathrm{O}-2.48, \mathrm{MgO}-3.23, \mathrm{Al}_{2} \mathrm{O}_{3}-18.90$, $\mathrm{SiO}_{2}-58.69, \mathrm{P}_{2} \mathrm{O}_{5}-0.05, \mathrm{~K}_{2} \mathrm{O}-0.36, \mathrm{CaO}-0.07, \mathrm{TiO}_{2}$ $-0.20, \mathrm{MnO}-0.08$ and $\mathrm{Fe}_{2} \mathrm{O}_{3}-3.54^{6}$. The $\mathrm{CaCO}_{3}$ and $\mathrm{Fe}_{2} \mathrm{O}_{3}$ were removed from the starting material by Jackson's method ${ }^{7}$. The $1 \%$ suspension of montmorillonite which was contacted with $1 \mathrm{M} \mathrm{NaCl}$, gives rise to the $\mathrm{Na}^{+}$montmorillonite form. The support was calcined for $5 \mathrm{~h}$ at the temperature of $723 \mathrm{~K}$. The investigated DESONOX catalysts were obtained by the double impregnation method with the EDTA and the $\mathrm{Na}_{4} \mathrm{~V}_{4} \mathrm{O}_{7}$ solutions. After each impregnation the support was dried in air and calcined. The scheme of catalysts preparation on different supports is presented in Figure 1.

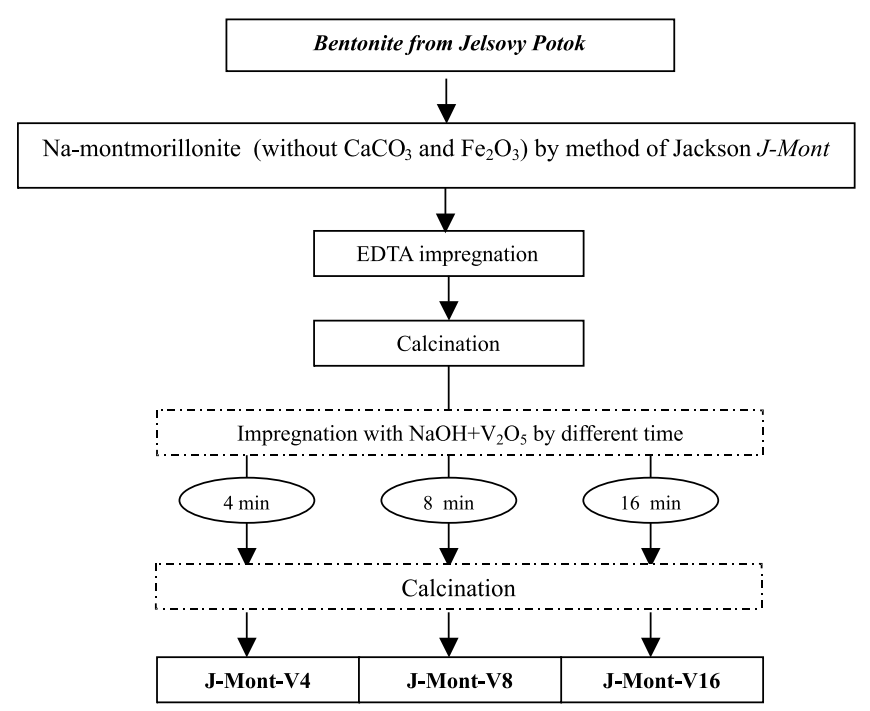

Figure 1. The scheme of catalysts preparation

\section{Methods}

The total surface areas of the examined catalysts were determined using the BET method by argon adsorption at boiling temperature of liquid nitrogen, in a volumetric apparatus ensuring a vacuum of at least $10^{-5} \mathrm{~mm} \mathrm{Hg}^{8}$. The concentrations of vanadium in the examined catalysts were determined by the XRF method ${ }^{5}$.

In order to study of catalysts the following experiment was carried out, coal combustion with catalysts. In this method hard coal from Silesian mine „Julian” from Poland was burnt with or without the catalysts using a flow reactor.

The concentration of sulphur dioxide in combustion gases was measured with the use of the VARIO PLUS exhaust analyzer. The proximate and ultimate analyses of hard coal are presented in Table 1. The mass ratio of the DESONOX catalyst added to the investigated samples of the hard coal was 1:500. Hard coal (without any addition) and hard coal with the catalyst addition were burnt in an 
Table 1. Proximate and ultimate analyses of hard coal. $\mathrm{W}^{\mathrm{a}}$ - moisture content, $\mathrm{A}^{\mathrm{a}}$ - ash content, $\mathrm{V}^{\text {daf }}$ - volatile matter content, $\mathrm{C}^{\mathrm{a}}$ - coal content, $\mathrm{H}^{\mathrm{a}}$ - hydrogen content, $\mathrm{N}^{\mathrm{a}}-$ nitrogen content, $\mathrm{S}_{\text {total }}^{\mathrm{a}}$ - total sulphur content

\begin{tabular}{|l|c|c|c|c|c|c|}
\hline \multirow{2}{*}{ Sample } & \multicolumn{3}{|c|}{ Proximate analysis (\%) } & \multicolumn{3}{c|}{ Ultimate analysis (\%) } \\
\cline { 2 - 6 } & $\mathrm{W}^{\mathrm{a}}$ & $\mathrm{A}^{\mathrm{a}}$ & $\mathrm{V}^{\text {daf }}$ & $\mathrm{C}^{\mathrm{a}}$ & $\mathrm{H}^{\mathrm{a}}$ & $\mathrm{S}^{\mathrm{a}}{ }_{\text {total }}$ \\
\hline \multirow{2}{*}{$\mathrm{WJ}$} & 5.0 & 5.9 & 37.5 & 71.3 & 4.23 & 1.24 \\
\hline
\end{tabular}

atmosphere of air at $1123 \mathrm{~K}$ for 4 hours and using an electric furnace.

Sulphur concentration into the samples of coal ashes, which included DESONOX catalysts, was determined by the XRF method. The hard coal uncombustionable degree was calculated on the basis of the sample weight before and after burning.

\section{Results and discussion}

Specific surface areas of the obtained supports based on montmorillonite are respectively: J-Mont $-45 \mathrm{~m}^{2} / \mathrm{g}$. After vanadium ions impregnation and calcination at the temperature of $723 \mathrm{~K}$, this parameter decreased, arranging the samples as follows: J-Mont-V4 $\left(7 \mathrm{~m}^{2} / \mathrm{g}\right)<\mathrm{J}$ Mont-V8 $\left(9 \mathrm{~m}^{2} / \mathrm{g}\right)<\mathrm{J}-$ Mont-V16 $\left(21 \mathrm{~m}^{2} / \mathrm{g}\right)$. Vanadium concentrations in the studied samples were about $2.3 \%$. The bulk densities $\delta$ of the catalysts are ca $1.1 \mathrm{~g} / \mathrm{cm}^{3}$.

The presented results of the DESONOX type catalysts show that impregnation of the montmorillonite with the use of vanadium, influences favorably the desulphurization process resulting in the reduction of sulphur dioxide emission in the exhaust gases.

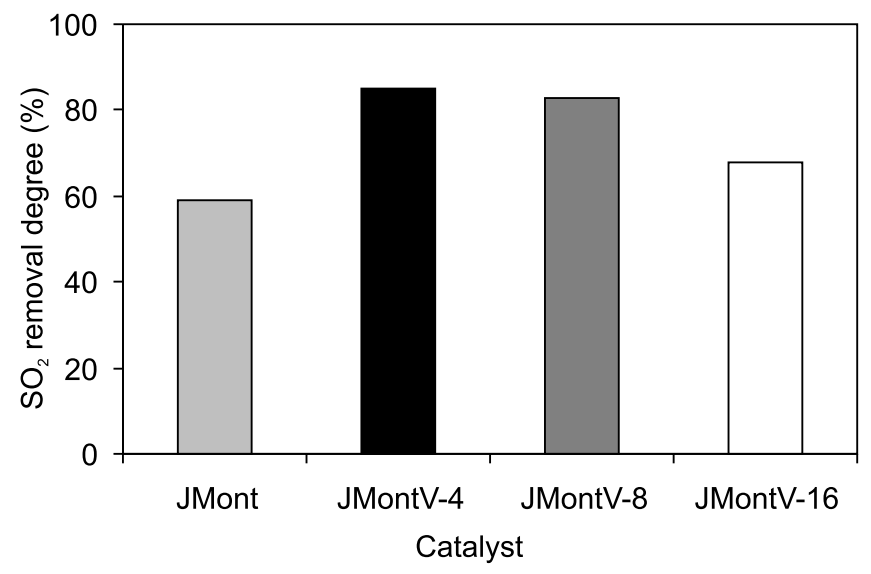

Figure 2. $\mathrm{SO}_{2}$ removal degree [\%] in the combustion process for the studied catalysts

From Fig. 2 of the presented $\mathrm{SO}_{2}$ removal degree, it may be seen that sulphur dioxide concentration in exhaust gases after hard coal with catalyst combustion is less than in an the absence of the catalyst. Combusting hard coal with the support of the $\mathrm{SO}_{2}$ only, the removal degree is $35 \%$, however, with catalyst it is as follows: J-Mont-V16 $(68 \%)<\mathrm{J}-$ Mont-V8 $(83 \%)<\mathrm{J}-$ Mont-V4 $(85 \%)$. From the compared catalytic activities $\left(\mathrm{SO}_{2}\right.$ removal degree) and the specific surfaces areas it may be seen that the catalyst with the smallest area has the bigger activity. Fig. 3 presents an example of $\mathrm{SO}_{2}$ concentration in combustion gases and the combustion time for the sample of hard coal WJ and hard coal WJ with the J-Mont-V4 catalyst.

The degree of non-afterburning in the samples with a catalyst equals about $14 \%$ for all the burned samples. No direct dependence between the degree of non-afterburning of the investigated coal and the size of the total surface

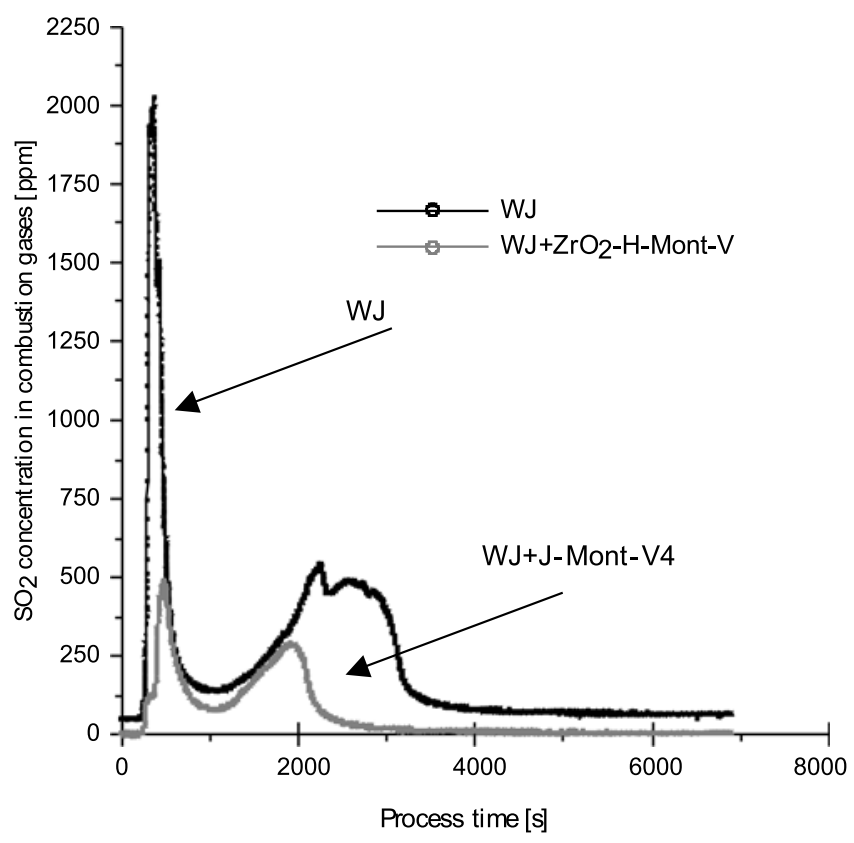

Figure 3. The relationship between $\mathrm{SO}_{2}$ concentration in combustion gases and the combustion time for the sample of hard coal WJ and hard coal WJ with the J-Mont-V4 catalyst

area of the catalysts has been observed. The used catalytic system with the catalysts based on the modified montmorillonite would make the introduction of technological changes in the process of the coal combustion possible, and would enhance the resignation from expensive, conventional methods of combustion gases purification, which include $\mathrm{SO}_{2}$.

\section{Conclusion}

According to the above-mentioned results of sulphur removal degree of the DESONOX type catalysts based on the modified montmorillonites, the following conclusions can be drawn:

- the addition of the DESONOX catalyst (coal to the catalyst mass ratio 500:1) containing vanadium results in the retention of $\mathrm{SO}_{2}$ in ashes within the range from $68 \%$ to $85 \%$,

- for the catalysts with montmorillonite supports the degree of sulphur removal formed a sequence: J-Mont $<$ J-Mont-V16 < J-Mont-V8 < J-Mont-V4,

- the degree of non-afterburning in samples with catalyst equals about $14 \%$ for all the burned samples.

- no direct dependence between the degree of nonafterburning of the investigated coal and the size of the total surface area of catalysts has been observed.

\section{LITERATURE CITED}

(1) Verhovnik V.: Research of function showing the dependence between FVK, $\mathrm{FEV}_{1}$ and the body height and mass being exposed to small concentrations of $\mathrm{SO}_{2}$ and smoke. Man and his Ecosystem, Proceeding of the $8^{\text {th }}$ World 
Clean Air Congress 1989, Ed. by Brasser L. J., Mulder W. C., Elsevier, Amsterdam-Oxford-New York-Tokyo 1989.

(2) Kucowski J., Laudyn D., Przekwas M.: Energetyka a Ochrona Środowiska, WNT, Warszawa 1994.

(3) Marcewicz-Kuba A., Nazimek D.: Influence of the Vanadium and Zinc Contents in DESONOX Catalysts on the Course of the DESOX Reaction, Ads. Sci. \& Technol., 16, 803, 1998.

(4) Marcewicz-Kuba A., Nazimek D.: Influence of Added Zeolite and Vanadium on the Physico-chemical Properties of DESONOX Catalysts, Pol. J. of Envir. Stud., 6, 29, 2000.

(5) Marcewicz-Kuba A., Nazimek D.: Influence of added molybdenum on the activity of DESONOX catalysts, Ads. Sci. \& Technol. 6, 549, 2002.

(6) Grzybek T., Klinik J., Olszewska D., Papp H., Smarzowski J.: The Influence of Montmorillonite Treatment on Structure, Sorption Properties and Catalytic Behaviour: Part I. Zirconia Pillared Clays Modified with Manganese as DENOX Catalysts. Polish J. Chem. 75, 857, 2001.

(7) Jackson M. L.: Soil chemical analysis, Prentice Hill, Englewood Cliffs, N.Y., (1958).

(8) Ościk J.: Adsorpcja, PWN, Warszawa 1983. 